\title{
Cultural Resources Survey of Portions of the Rio Bravo LNG Pipeline on Port of Brownsville Lands, Cameron County, Texas
}

Steve Carpenter

SWCA

Christina Nielsen

SWCA

Jessica Ulmer

Mercedes C. Cody

SWCA

Janaka Greene

Follow this and additional works at: https://scholarworks.sfasu.edu/ita

Part of the American Material Culture Commons, Archaeological Anthropology Commons, Environmental Studies Commons, Other American Studies Commons, Other Arts and Humanities Commons, Other History of Art, Architecture, and Archaeology Commons, and the United States History Commons

Tell us how this article helped you.

This Article is brought to you for free and open access by the Center for Regional Heritage Research at SFA ScholarWorks. It has been accepted for inclusion in Index of Texas Archaeology: Open Access Gray Literature from the Lone Star State by an authorized editor of SFA ScholarWorks. For more information, please contact cdsscholarworks@sfasu.edu. 


\section{Cultural Resources Survey of Portions of the Rio Bravo LNG Pipeline on Port of Brownsville Lands, Cameron County, Texas}

\section{Creative Commons License}

\section{(c) (1) \&}

This work is licensed under a Creative Commons Attribution-NonCommercial 4.0 International License 


\section{Cultural Resources Survey of Portions of the Rio Bravo LNG Pipeline on Port of Brownsville Lands, Cameron County, Texas}

APRIL 2020

TEXAS ANTIQUITIES PERMIT NO. 8588

PREPARED FOR

Ecology and Environment, Inc.

PREPARED BY

SWCA Environmental Consultants

Redacted 



\title{
CULTURAL RESOURCES SURVEY OF PORTIONS OF THE RIO BRAVO LNG PIPELINE ON PORT OF BROWNSVILLE LANDS, CAMERON COUNTY, TEXAS
}

\author{
Prepared for \\ Ecology and Environment, Inc. \\ 2 Riverway, Suite 625 \\ Houston, Texas 77056
}

Prepared by

Steve Carpenter, Christina Nielsen, Jessica Ulmer, Mercedes C. Cody, and Janaka Greene

Principal Investigator

Steve Carpenter, M.A.
SWCA Environmental Consultants
4407 Monterey Oaks Boulevard
Building 1, Suite 110
Austin, Texas 78749
www.swca.com

Texas Antiquities Permit 8588

SWCA Project No. 32334

SWCA Cultural Resources Report

April 2020 



\section{ABSTRACT}

On behalf of Ecology and Environment, Inc. (E \& E), Rio Grande LNG, LLC, and Rio Bravo Pipeline Company, LLC (RB Pipeline), SWCA Environmental Consultants (SWCA) conducted cultural resources surveys of portions of the Rio Bravo Pipeline on lands owned or controlled by the Port of Brownsville in Cameron County, Texas. Rio Grande LNG, LLC proposes to construct a natural gas liquefaction facility and liquefied natural gas (LNG) export terminal (Terminal) in Cameron County, Texas, along the north embankment of the Brownsville Ship Channel. In concert with the Terminal, RB Pipeline proposes to construct an associated pipeline system (Pipeline System/Project) within Cameron, Willacy, Kenedy, Kleberg, and Jim Wells Counties, Texas to allow for interconnection with a network of existing pipelines that traverse the northern end of Kleberg County and Jim Wells County. The proposed Pipeline System/Project will collect and transport natural gas to the Terminal site. In compliance with the Federal Energy Regulatory Commission and U.S. Army Corps of Engineers permitting requirements and oversight, SWCA conducted cultural resources investigations in compliance with Section 106 of the National Historic Preservation Act (NHPA) (54 U.S.C. 306108) and its implementing regulations in 36 Code of Federal Regulations 800. Although the entire Project is subject to compliance with Section 106 of the NHPA, this stand-alone report specifically addresses portions of the alignment that will be located on lands owned by the Port of Brownsville (Port). Since the Port is a political subdivision of the state, investigations were conducted in compliance with the Antiquities Code of Texas (ACT) under ACT Permit No. 8588 administered by the Texas Historical Commission (THC). The data in this report is also presented in Addendum IV (Carpenter et al., 2020) to the final report (Nielsen et al., 2016) of the overall investigations.

The investigations covered 0.58 mile $(0.93$ kilometers $[\mathrm{km}])$ of proposed pipeline corridor within a 200 foot-wide (60.96-meter [m]-wide) pipeline survey corridor, and 0.31 mile $(0.50 \mathrm{~km})$ of proposed access roads within a 50-foot-wide (15.24-m-wide) access roads survey corridor, for a Project Area total of approximately 15.8 acres within Port property. The cultural resources investigations included a background and historical map review, and an intensive pedestrian survey with subsurface testing. The background review identified nine previously conducted archaeological surveys within a 1-mile radius of the Project Area, three of which intersect the current Project Area. The background review identified no previously recorded archaeological sites within the Project Area; however, seven archaeological sites are within a 1-mile radius none of which are immediately adjacent (within 300 feet $[91.44 \mathrm{~m}]$ ) to the Project Area. In addition, a review of historical maps determined that there are no historic-age structures or features mapped within or immediately adjacent to the Project Area.

SWCA archaeologists conducted the cultural resources intensive pedestrian survey on October 22, 2018. The investigation revealed an extensively disturbed setting due to historic \& modern development in the area mainly associated with the Port. SWCA archaeologists excavated a total of nine shovel tests within the Project Area all negative for cultural materials. No cultural materials or features or historic-age structures were identified within the Project Area during the field survey.

In accordance with the ACT and Section 106 of the NHPA, SWCA has made a reasonable and good faith effort to identify cultural resources within the Project Area of Potential Effects (APE). No cultural resources were identified within the Project Area during the current investigations. Accordingly, no further investigation is recommended for the assessed sections of the Project Area. The THC concurred with these findings and recommendations on January 14, 2020. No artifacts were recovered; documentation will be curated at the Texas Archeological Research Laboratory of The University of Texas at Austin. 
Cultural Resources Survey of Portions of the Rio Bravo LNG Pipeline on Port of Brownsville Lands Antiquities Code of Texas Permit 8588

This page intentionally left blank. 


\section{CONTENTS}

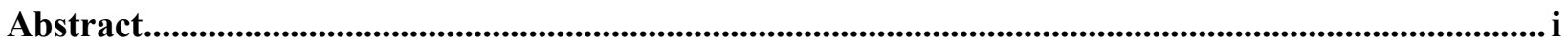

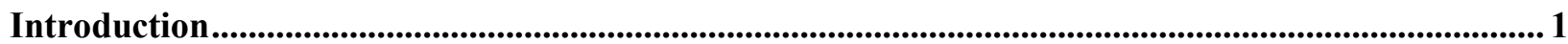

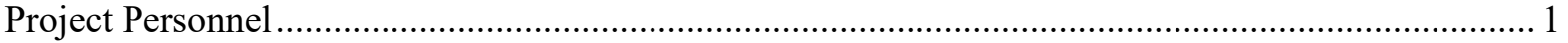

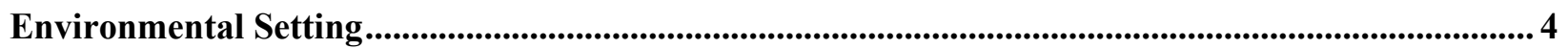

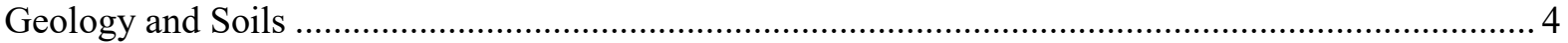

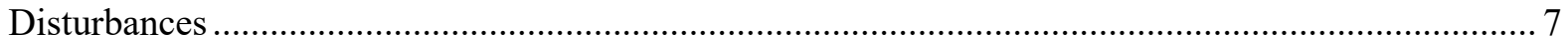

Cultural resources Desktop Review ............................................................................................

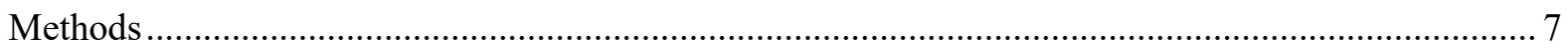

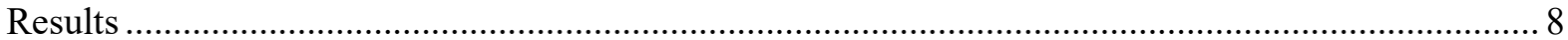

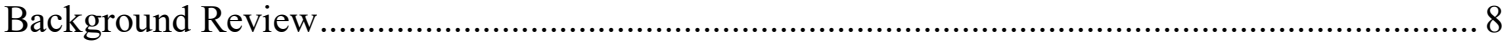

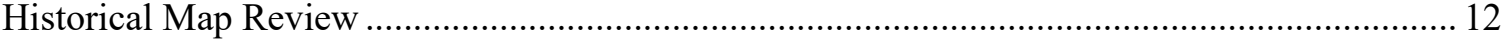

Field Survey ........................................................................................................................................... 12

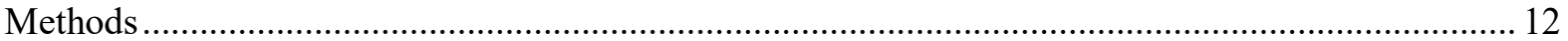

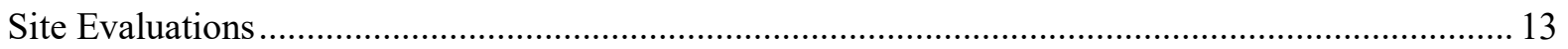

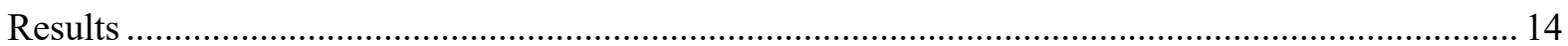

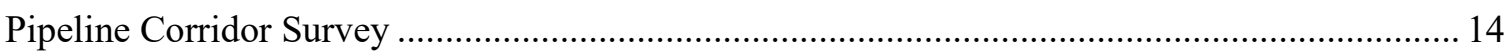

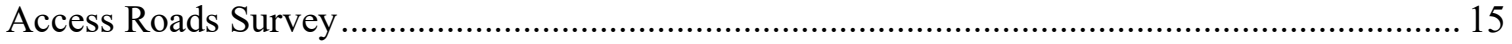

Summary and Recommendations......................................................................................................... 19

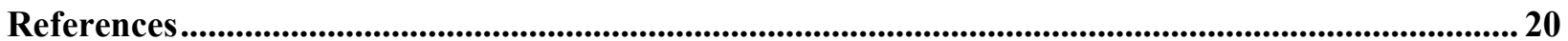

Figures

Figure 1. Project location map..............................................................................................

Figure 2. Aerial map showing Project Area................................................................................ 3

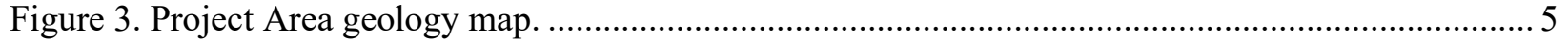

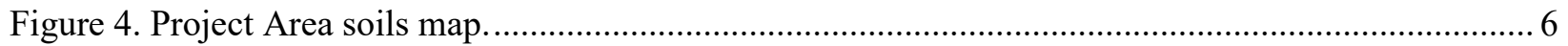

Figure 5. Background review results map. ………………................................................. 9

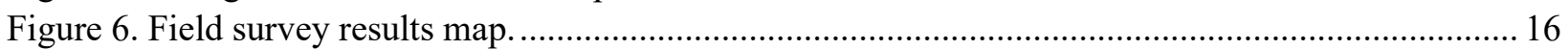

Figure 7. Overview of loma on ND-CAM-082.000, facing southeast.................................................... 18

Figure 8. Existing access road on tract ND-CAM-082.000, facing south. Access road has long been in use for existing collocated pipeline marked by orange and white posts in background. Note wide road cut through low lomas near surveyor.

\section{Tables}

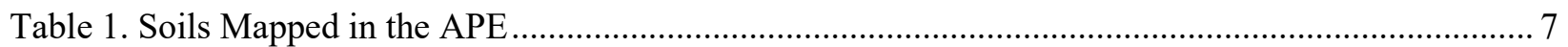

Table 2. Previously Conducted Archaeological Surveys within a 1-mile Radius of the APE................... 10

Table 3. Previously Recorded Archaeological Sites within a 1-mile Radius of the APE......................... 11

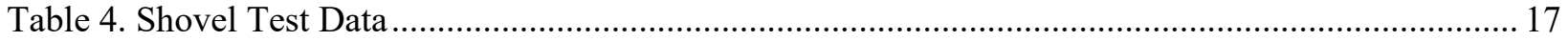


Cultural Resources Survey of Portions of the Rio Bravo LNG Pipeline on Port of Brownsville Lands Antiquities Code of Texas Permit 8588

This page intentionally left blank. 


\section{INTRODUCTION}

Rio Grande LNG, LLC, proposes to construct a natural gas liquefaction facility and liquefied natural gas (LNG) export terminal (Terminal) in Cameron County, Texas, along the north embankment of the Brownsville Ship Channel. In concert with the Terminal, Rio Bravo Pipeline Company, LLC (RB Pipeline), proposes to construct an associated pipeline system (Project) within Cameron, Willacy, Kenedy, Kleberg, and Jim Wells Counties, Texas to allow for interconnection with a network of existing pipelines that traverse the northern end of Kleberg County and Jim Wells County. The proposed pipeline system will collect and transport natural gas to the Terminal site. In compliance with the Federal Energy Regulatory Commission (FERC) and U.S. Army Corps of Engineers (USACE) permitting requirements and oversight, SWCA Environmental Consultants (SWCA) conducted work in compliance with Section 106 of the National Historic Preservation Act (NHPA) (54 U.S.C. 306108) and its implementing regulations in 36 Code of Federal Regulations (CFR) 800. Although the entire Project is subject to compliance with Section 106 of the NHPA, this stand-along report specifically addresses portions of the alignment that will be located on lands owned by the Port of Brownsville (Port). Since the Port is a political subdivision of the state, investigations were conducted in compliance with the Antiquities Code of Texas (ACT) under ACT Permit No. 8588 administered by the Texas Historical Commission (THC).

The project spans approximately 15.8 acres of lands owned by the Port located approximately 8.0 miles (12.88 kilometers $[\mathrm{km}]$ ) northeast of Brownsville in Cameron County, Texas (Figures 1 and 2). This report details the findings of investigations within the portions of the Project located on Port property under Antiquities Code of Texas Permit No. 8588. The cultural resources investigations included a background and historical map review, and an intensive pedestrian survey with subsurface testing. The investigations covered 0.58 mile $(0.93$ kilometers $[\mathrm{km}])$ of proposed pipeline corridor within a 200 -footwide (60.96-meter [m]-wide) pipeline survey corridor, and 0.31 mile $(0.50 \mathrm{~km})$ of proposed access roads within a 50-foot-wide (11.24-m-wide) access roads survey corridor total Project Area of Potential Effects (APE). The data in this report is also presented in Addendum IV (Carpenter et al., 2020) to the final report (Nielsen et al., 2016) the overall investigations.

The goal of this investigation was to identify all prehistoric and historic cultural resources within the project area, establish vertical and horizontal site boundaries as appropriate within the project area, and evaluate the significance and eligibility of any cultural resources according to eligibility criteria for the National Register of Historic Places (NRHP) and for designation as a State Antiquities Landmark (SAL). This investigation followed the guidelines and procedures outlined in the Council of Texas Archeologists (CTA) standards for cultural resources investigations and the ACT, as outlined in the THC's Rules of Practice and Procedure for the Antiquities Code of Texas. The investigations within Port property, conducted in October 2018, reflect the Project footprint as of February 2020. These studies contribute to the ongoing comprehensive cultural resources assessment of the Project.

\section{Project Personnel}

Steve Carpenter, M.A., served as Principal Investigator and Project Manager for the duration of the Project, overseeing overall logistics and organization, and managing reporting, field investigations, and agency consultation. Cultural Resources Director Martin Handly provided oversight and quality control throughout the process. Field Director Christopher Shelton, M.A. and Archaeologists Michael Golden, Jessica Ulmer, Rachel Jenson, Ben Morton, and David Keim conducted the field survey. Carole Carpenter produced all field and report maps, and Lauri Logan provided technical editing and document preparation for the Project. 


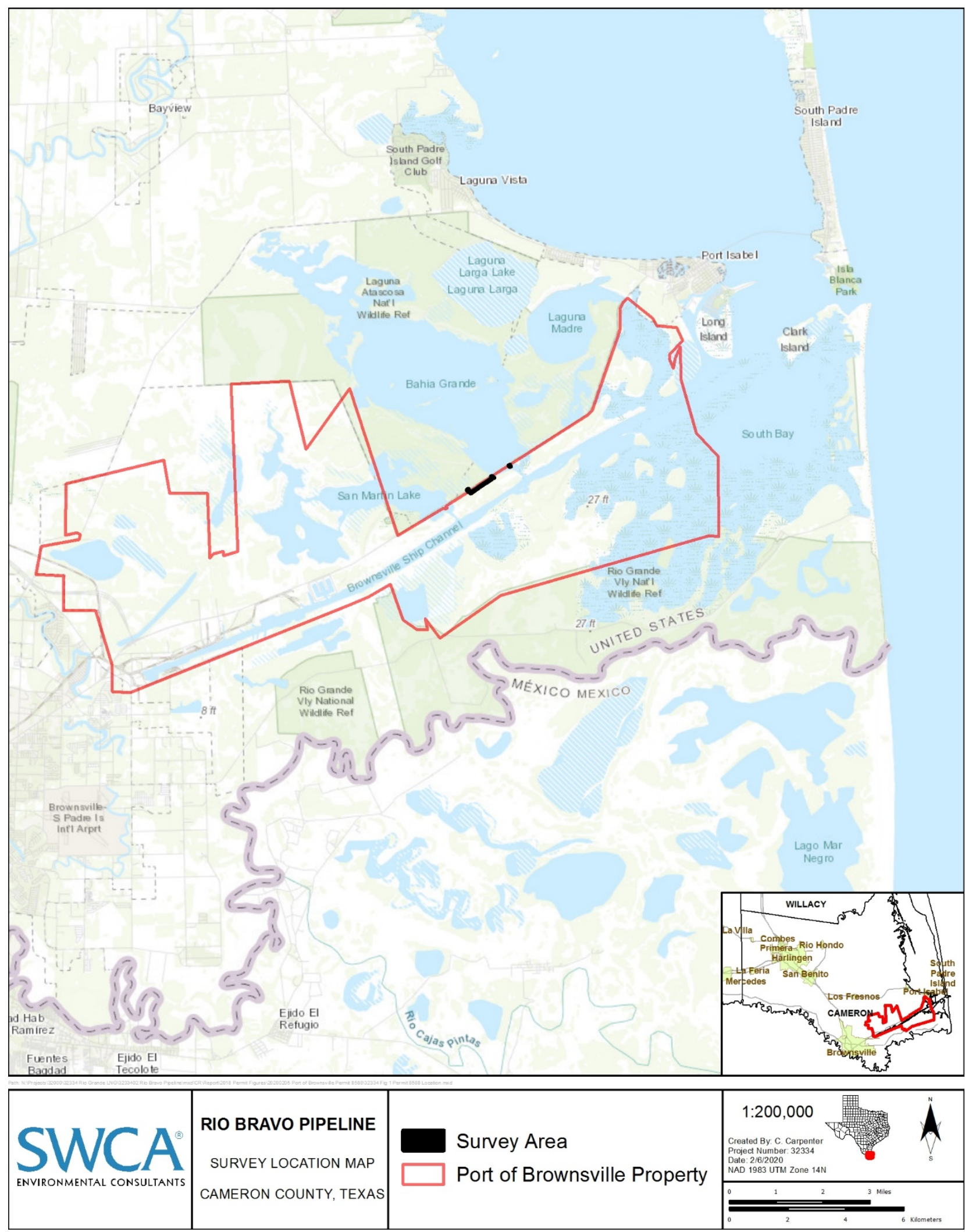

Figure 1. Project location map. 


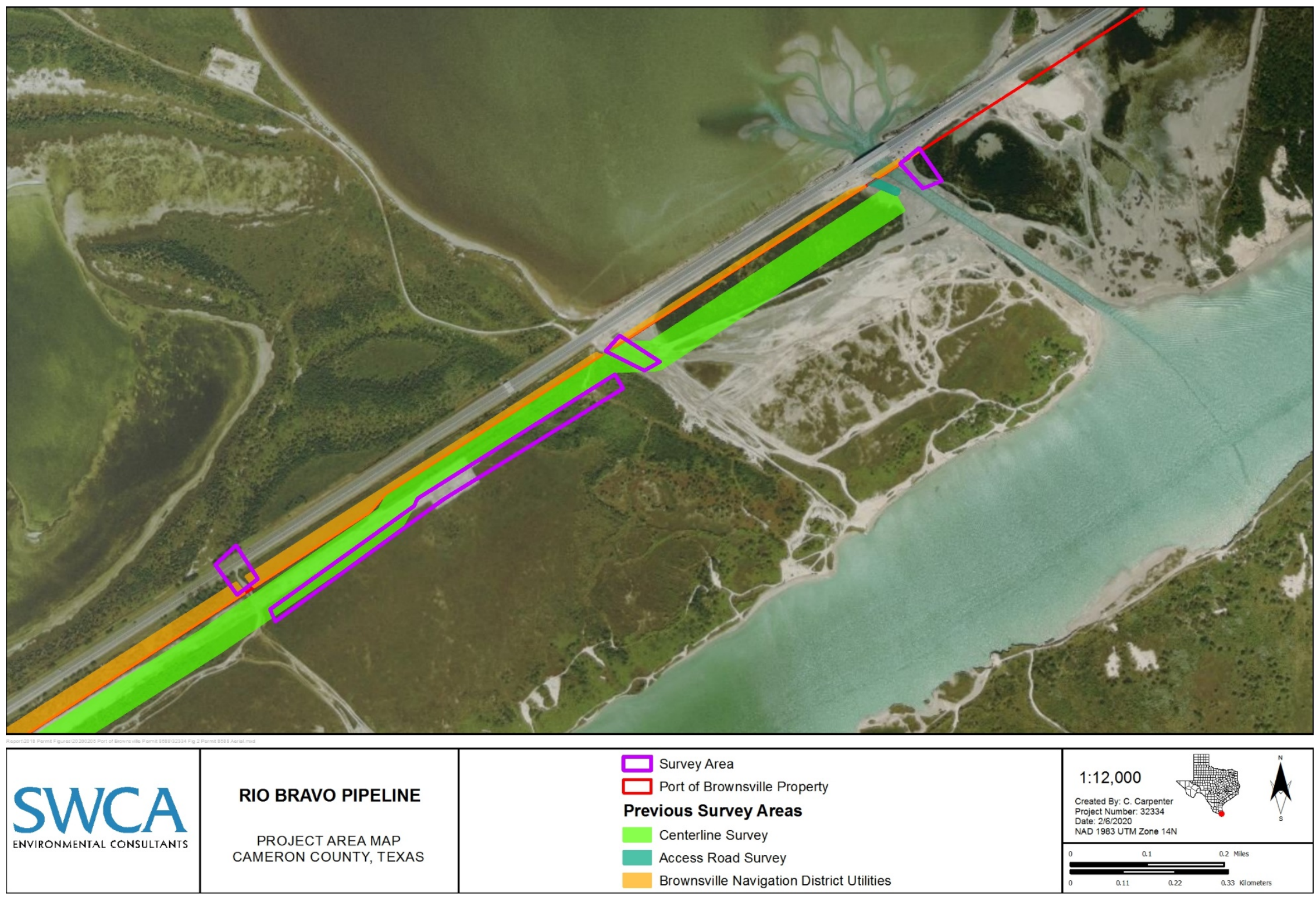

Figure 2. Aerial map showing Project Area. 


\section{ENVIRONMENTAL SETTING}

The Project area falls within the South Texas Plains geographic region in Texas, stretching from Cameron County in the southeast to Kinney County in the northwest (Arbingast et al. 1973). The South Texas Plains is considered largely mesquite brush country, although the region has significant environmental variation. Black (1989:Figure 19) defines five subdivisions, or biogeographical areas, that encompass the region: the Rio Grande Plain, the Rio Grande Delta, the Nueces-Guadalupe Plain, the Sand Sheet, and the Coastal Bend (this includes a portion of the Gulf Coastal Plain geographic region defined by Arbingast et al. [1973]). Of these, the Project Area traverses the Rio Grande Delta. The Rio Grande Delta encompasses Kenedy (southern strip), Willacy, Cameron and Hidalgo Counties.

The Project Area is situated on the Rio Grande Delta on the coastal plain and barrier island area of far southern Texas. The Brownsville Ship Channel runs along the southern margin, San Martin Lake borders the northwestern western margin, Bahia Grande borders and State Highway (SH) 48 runs along the northern margin (see Figure 2). The APE comprises three main landforms: low-lying tidal areas and water bodies; flats that are predominantly covered with spoil/dredge; and lomas, small hills formed by stabilized dunes.

\section{Geology and Soils}

Surface geology of the Rio Grande Delta area comprises Tertiary (2-66 million years ago) and Quaternary (2 million years ago to present) formations, which are primarily floodplain deposits of stratified, Holocene sands, silts, clays, and gravels (Barnes 1976). The Project Area is geologically mapped as Quaternary Alluvium in Rio Grande, subdivided into predominantly clay areas, Quaternary Tidal Flat areas, and Fill and Spoil areas (Figure 3). Roughly half of the Project Area is mapped as Tidal Flat Areas. Tidal flats include clay, silt, sand, gravel, and organic matter, but predominantly mud (Fisher 1976). This is followed by roughly one third of the Project Area mapped as Rio Grande Alluvium, subdivided into areas of predominantly clay. Areas predominantly of clay include floodplain and backswamp silt and clay (Fisher 1976). The remaining portions of the Project Area are mapped as fill and spoil deposits that consist of dredged material along waterways. These sediments include mud, silt, sand and shell (Fisher 1976).

There are four soil units mapped within the APE (Figure 4; Table 1) (Natural Resources Conservation Service [NRCS] 2019) discussed in order of prevalence. The majority of the Project Area is mapped as Ustifluvents (dredge material. Ustifluvents consist of clayey dredge materials, secondarily deposited during construction of nearby canals and the Port of Brownsville waterway. Point Isabel clay loam found on lomas (small dunal formations) where many prehistoric sites have been recorded. These soils consist of clayey eolian deposits on the shoulder and backslope of rises and are up to 65 inches thick. Barrada clays are found on tidal flats. These poorly drained soils consist of clayey over loamy alluvium. Sejita silty clay loam is typically found only a few feet above sea level along the high-water mark. The surface layer is a light brownish-gray calcareous silt loam that is 2 inches thick. Below, to a depth of 20 inches, is a light-gray silty clay loam. The underlying material, to a depth of 40 inches, is a very pale brown stratified silty loam, silty clay loam, or clay loam. 


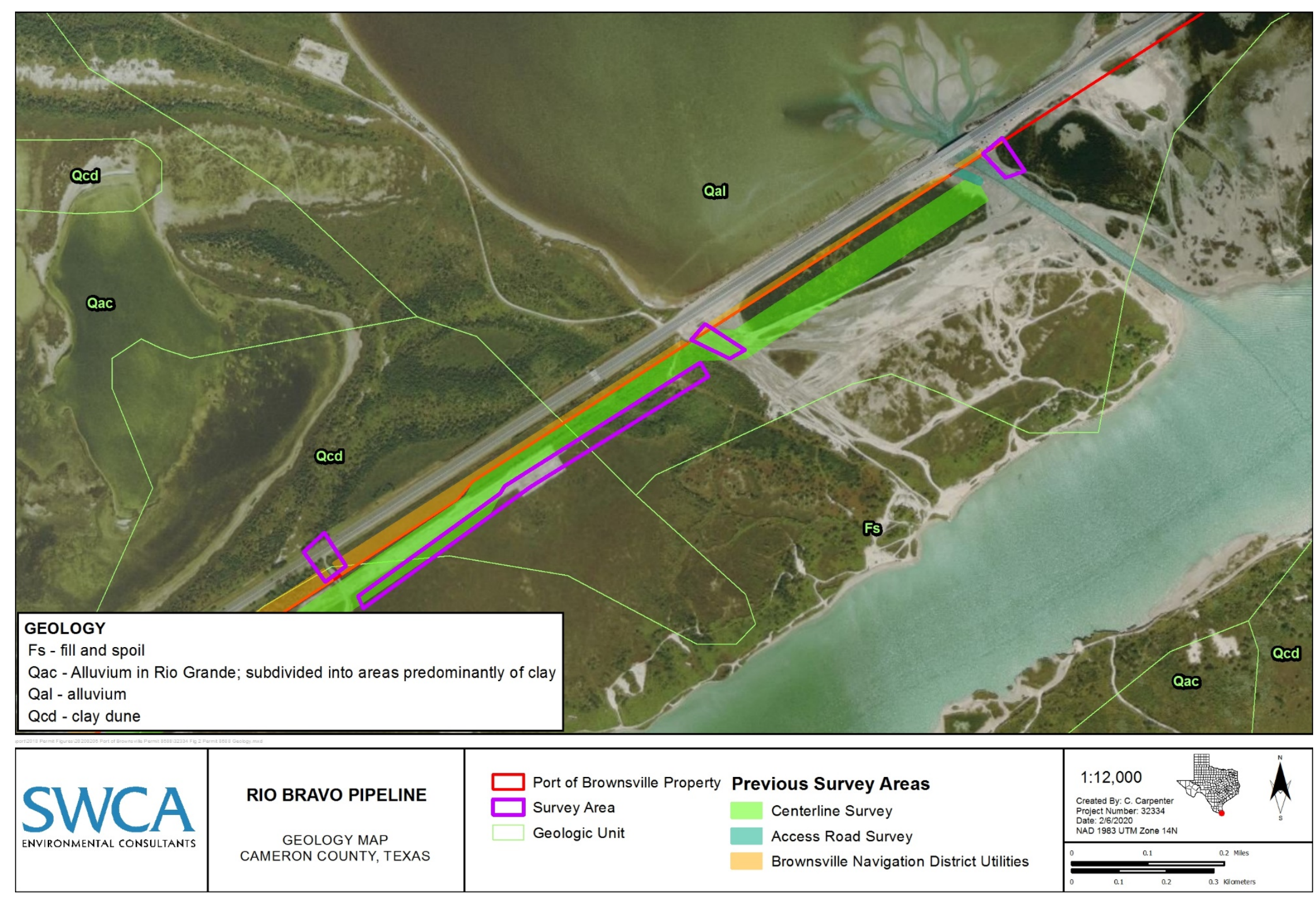

Figure 3. Project Area geology map. 


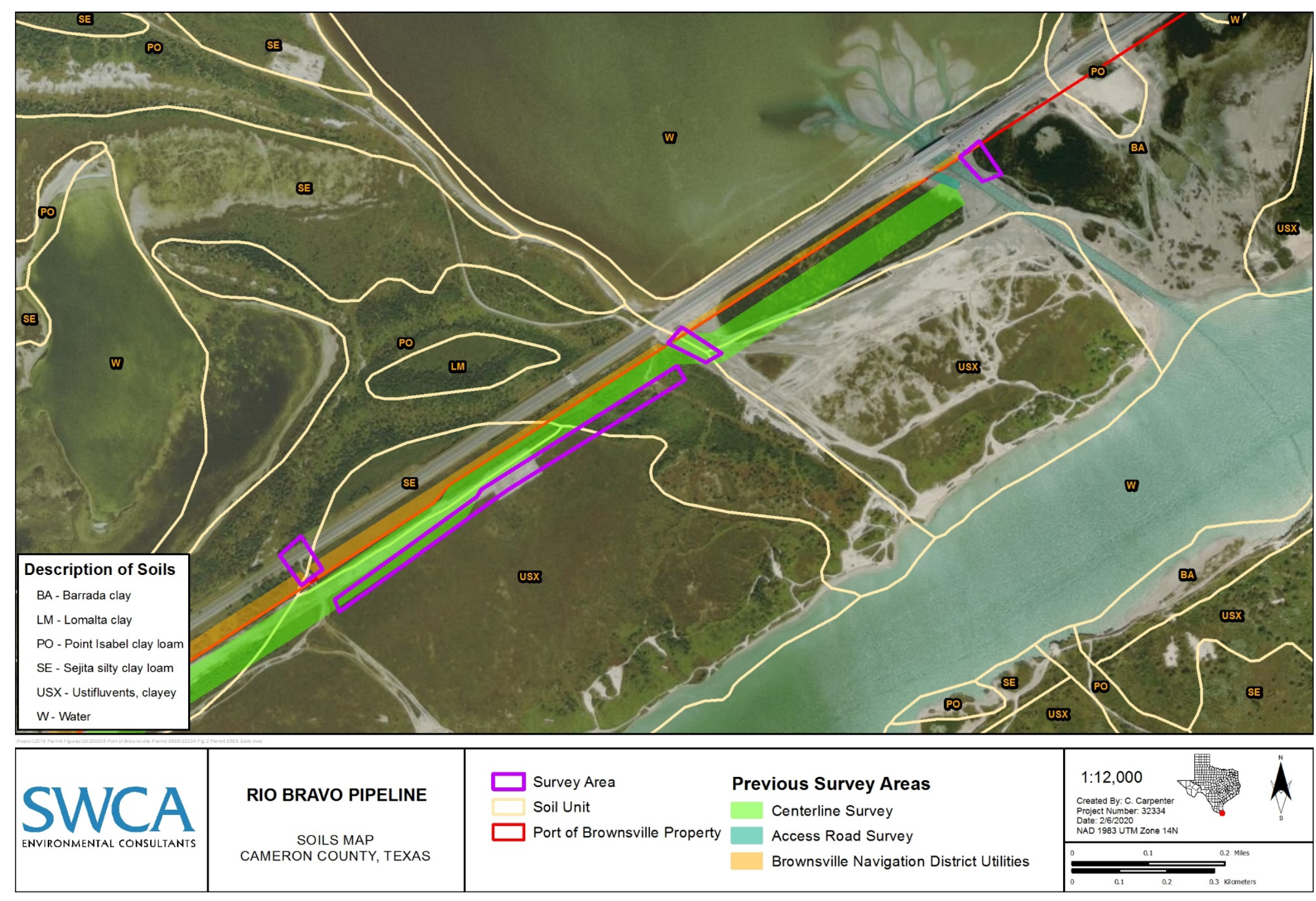

Figure 4. Project Area soils map. 
Table 1. Soils Mapped in the APE

\begin{tabular}{cccc}
\hline Map Unit Name & Map Unit Symbol & Description & $\begin{array}{c}\text { Archaeological } \\
\text { Potential }\end{array}$ \\
\hline Barrada clay & BA & Tidal; flats & Low \\
\hline Point Isabel clay loam & PO & Clayey eolian deposits on lomas & High \\
\hline Sejita silty clay loam & SE & Eolian or alluvial sediments & Moderate \\
\hline Ustifluvents, clayey & USX & Dredge materials & Low \\
\hline
\end{tabular}

\section{Disturbances}

Noted disturbances within the project area are mostly limited to previous spoil deposition that derived from the construction of the Brownsville Ship Channel. Other disturbances include grading and clearing of utilities along the south side of SH 48 (overhead and subsurface). Further information on previous disturbances will be obtained during the field survey of the proposed pipeline alignment.

\section{CULTURAL RESOURCES DESKTOP REVIEW}

SWCA performed a cultural resources desktop review in September 2018 and October 2019. The desktop review consisted of a background and historical map review focused on the Project Area, as well as a 1mile-buffer (1.6-km-buffer) around the Project Area (i.e., the review area).

\section{Methods}

SWCA performed a background review to determine if the proposed APE has been previously surveyed for cultural resources or if any archaeological sites have been recorded within or adjacent to the APE. To conduct the background review, an SWCA archaeologist reviewed portions of the Laguna Vista and Palmitto Hill, Texas, U.S. Geological Survey (USGS) 7.5-minute topographic quadrangle maps, as well as archaeological site and survey records on the Texas Archeological Sites Atlas (Atlas) online database (THC 2018 and 2019). These sources provided information on the nature and location of previously conducted archaeological surveys, previously recorded archaeological sites, locations of NRHP districts and properties, sites designated as SALs, Official Texas Historical Markers, Recorded Texas Historic Landmarks, cemeteries, and local neighborhood surveys. However, the Atlas does not list all previous work conducted within a specific area. Previous cultural resources investigations listed on the Atlas are limited to projects under purview of the ACT or the National Historic Preservation Act of 1966, as amended. Also, recent projects under these regulations may not be posted on the Atlas due to a delay between the completion of fieldwork and the completion of the report.

As a part of the historical map review, an SWCA archaeologist reviewed the Texas Department of Transportation Historic Overlay (Foster et al. 2006), a mapping/GIS database with historical maps and resource information covering most portions of the state, and the USGS historical topographic maps available on the USGS TopoView website (USGS 2015). In addition, archaeologists reviewed modern aerial imagery to identify land use practices that may indicate the potential for or presence of cultural resources within the project area. 


\section{Results}

The background and historical map review results that pertain specifically to areas addressed in this report are provided herein, deferring to the previous reports (i.e., Stotts and Carpenter 2015; Nielsen et al. 2016; Carpenter et al. 2020) for a more sustained discussion of the results relative to the overall Pipeline System/Project. The original 2015 background reviews were updated in September 2018 and October 2019.

\section{Background Review}

The background review identified nine previously conducted archaeological surveys within a 1-mile radius of the APE, three of which intersect the Project Area (Figure 5; Table 2). The background review identified no previously recorded archaeological sites within the APE; however, seven archaeological sites are within a 1-mile radius none of which are immediately adjacent (within 300 feet [91.44 $\mathrm{m}]$ ) to the Project Area (Figure 5; Table 3).

Nine previously conducted archaeological surveys are mapped within a 1-mile radius of the APE, three of which intersect the Project Area (see Figure 5; see Table 2). Of the three surveys that intersect, one linear survey was conducted in July 1992 on behalf of the U. S. Army Corps of Engineers (USACE) Galveston District; no sites were recorded within the current Project Area during this investigation (THC 2018 and 2019). In 2004, Coastal Environments, Inc. conducted surveys of select high probability areas along SH 48 on behalf of the Texas Department of Transportation (TxDOT) that intersects the current APE; no sites were recorded within the current Project Area during these investigations (Weinstein et al., 2005). In April 2015, SWCA conducted a survey of the proposed 1,000-acre Rio Grande LNG Export Terminal Project on behalf of EE and NextDecade, LLC, in compliance with FERC and USACEGalveston District located along the Brownsville Ship Channel in the Rio Grande Delta that recorded no sites within the current Project Area (Stotts and Carpenter 2015).

Seven sites are recorded within a 1-mile radius of the APE none of which are immediately adjacent (within 300 feet [91.44 m]) to the Project Area (see Figure 5; see Table 3). Three of the sites are open prehistoric campsites and four are prehistoric artifact scatters. Four of the sites were recommended as not eligible and three are undetermined with regard to NRHP and SAL designation eligibility (THC 2018 and 2019). 


\section{Restricted Information}

Not for Public Disclosure

Figure 5. Background review results map. 
Cultural Resources Survey of Portions of the Rio Bravo LNG Pipeline on Port of Brownsville Lands Antiquities Code of Texas Permit 8588

\section{Table 2. Previously Conducted Archaeological Surveys within a 1-mile Radius of the APE}

\begin{tabular}{|c|c|c|c|c|c|c|c|}
\hline Quad Map & Location in relation to APE & $\begin{array}{c}\text { Project } \\
\text { Type }\end{array}$ & $\begin{array}{l}\text { Fieldwork } \\
\text { Date }\end{array}$ & Agency & Investigating Firm & $\begin{array}{l}\text { Project } \\
\text { Planner }\end{array}$ & Project Name \\
\hline Palmito Hill & Within 1-mile of APE & Linear & $00 / 74$ & USACE-GAL & Unknown & $\mathrm{n} / \mathrm{a}$ & Unknown \\
\hline $\begin{array}{l}\text { Laguna Vista, } \\
\text { Palmito Hill }\end{array}$ & Within 1-mile of APE & Linear & $00 / 81$ & USACE-GAL & Unknown & $\mathrm{n} / \mathrm{a}$ & Unknown \\
\hline Palmito Hill & Within 1-mile of APE & Linear & $5 / 1 / 1981$ & USACE-GAL & Unknown & $\mathrm{n} / \mathrm{a}$ & Unknown \\
\hline $\begin{array}{l}\text { Palmito Hill, } \\
\text { Port Isabel }\end{array}$ & Within 1-mile of APE & Area & $10 / 1 / 1986$ & USACE-GAL & Unknown & $\mathrm{n} / \mathrm{a}$ & Unknown \\
\hline Laguna Vista & Intersects APE & Linear & $7 / 1 / 1992$ & USACE-VD & Unknown & $\mathrm{n} / \mathrm{a}$ & Survey \\
\hline $\begin{array}{l}\text { Laguna Vista, } \\
\text { Palmito Hill }\end{array}$ & Intersects APE & Area & $9 / 1 / 2004$ & TxDOT & Coastal Environments Inc. & $\mathrm{n} / \mathrm{a}$ & $\begin{array}{c}\text { CHS of Six Areas Along } \\
\text { SH48 }\end{array}$ \\
\hline Laguna Vista & Within 1-mile of APE & Area & $12 / 10 / 2004$ & USFWS & Coastal Environments Inc. & Ocean Trust & $\begin{array}{c}\text { Additional Intensive } \\
\text { Survey at 41CF136, with } \\
\text { Revised Assessment and } \\
\text { Recommendations }\end{array}$ \\
\hline $\begin{array}{l}\text { Laguna Vista, } \\
\text { Palmito Hill } \\
\end{array}$ & Within 1-mile of APE & Area & $9 / 21 / 2009$ & USFWS & Blanton \& Associates, Inc. & $\begin{array}{l}\text { Sanchez Oil } \\
\text { and Gas, Inc. }\end{array}$ & $\begin{array}{c}\text { Laguna Atascosa Nationa } \\
\text { Wildlife Refuge }\end{array}$ \\
\hline Multiple & Intersects APE & Area & $4 / 13-17 / 2015$ & $\begin{array}{l}\text { FERC \& } \\
\text { USACE }\end{array}$ & SWCA & $\mathrm{n} / \mathrm{a}$ & $\begin{array}{c}\text { Rio Grande LNG Termina } \\
\text { Facility }\end{array}$ \\
\hline
\end{tabular}

Highlighted rows denote investigations in or immediately adjacent to the APE. 
Cultural Resources Survey of Portions of the Rio Bravo LNG Pipeline on Port of Brownsville Lands

Table 3. Previously Recorded Archaeological Sites within a 1-mile Radius of the APE

\begin{tabular}{|c|c|c|c|c|c|c|c|}
\hline Trinomial & $\begin{array}{l}\text { Location in } \\
\text { relation to APE }\end{array}$ & Site Type & Time Period & $\begin{array}{l}\text { Eligibility } \\
\text { Status }\end{array}$ & Recommendations & Comments & Project \\
\hline $41 \mathrm{CF} 48$ & $\begin{array}{c}\text { Within 1-mile of } \\
\text { APE }\end{array}$ & Artifact scatter & Not reported & Undetermined & Testing & Shell, bone, and odoliths & Cameron Co. Survey 1970 \\
\hline 41CF49 & $\begin{array}{l}\text { Within 1-mile of } \\
\text { APE }\end{array}$ & Artifact scatter & Not reported & Not eligible & None & Shell and bone & Cameron Co. Survey 1970 \\
\hline 41CF138 & $\begin{array}{l}\text { Within 1-mile of } \\
\text { APE }\end{array}$ & Open campsite & $\begin{array}{l}\text { Late Prehistoric } \\
\text { and Early } \\
\text { Historic }\end{array}$ & Not eligible & None & $\begin{array}{l}\text { Disc-shaped conch whorl } \\
\text { bead blank, mano end } \\
\text { scraper, greatly reduced } \\
\text { trench musket flint. }\end{array}$ & $\begin{array}{l}\text { Survey of Rangia Cuneata } \\
\text { in Cameron Co., COE } 1992\end{array}$ \\
\hline 41CF190 & $\begin{array}{c}\text { Within 1-mile of } \\
\text { APE }\end{array}$ & Open campsite & Prehistoric & Undetermined & Not reported & $\begin{array}{c}\text { Variety of shell, flake sunray } \\
\text { venus }\end{array}$ & SH 48, TxDOT 2004 \\
\hline 41CF191 & $\begin{array}{l}\text { Within 1-mile of } \\
\text { APE }\end{array}$ & Open campsite & Prehistoric & Undetermined & Not reported & $\begin{array}{c}\text { Cluster of pen shells and } \\
\text { oyster shell }\end{array}$ & SH 48, TxDOT 2004; \\
\hline 41CF221 & $\begin{array}{c}\text { Within 1-mile of } \\
\text { APE }\end{array}$ & Artifact scatter & Prehistoric & Not eligible & None & $\begin{array}{l}\text { Shell, bone, and burned clay } \\
\text { on eroded slope }\end{array}$ & $\begin{array}{l}\text { Annova LNG Brownsville } \\
\text { Project, Blanton } 2015\end{array}$ \\
\hline 41CF222 & $\begin{array}{l}\text { Within 1-mile of } \\
\text { APE }\end{array}$ & Artifact scatter & Prehistoric & Not eligible & None & $\begin{array}{l}\text { Shell, bone, manuport, and } \\
\text { burned clay }\end{array}$ & $\begin{array}{l}\text { Annova LNG Brownsville } \\
\text { Project, Blanton } 2015\end{array}$ \\
\hline
\end{tabular}




\section{Historical Map Review}

A review of historical maps determined that there are no historic-age structures or features within or immediately adjacent to the Project Area. The review of the TxDOT Historic Overlay maps determined there are no historic-age structures within or adjacent to the APE (Foster et al. 2006). Furthermore, a review of historical topographic maps and aerial photography did not identify any historic-age structures within the Project Area. The review did, however, identify land ownership of the Port of Brownsville area for different years.

The earliest maps reviewed of the Port of Brownsville area are an $1867 \mathrm{H}$. Holtz map of Texas and an 1853 map of the U.S.-Mexico Border for Guadalupe and Hidalgo. These maps illustrate a single trail intersecting the western portion of the Port property from the southeast to the northwest. This trail is a part of a network of trails that cover the state of Texas and parts of Mexico (Foster et al. 2006).

Three maps of Cameron County from 1873, 1880, and 1884 depict land grants within the Port of Brownsville area. The 1873 E. Schutze map identifies the Port of Brownsville area as land grant 1.418 Heirs of Rafael Garcia, also known as "Potrero de la Santa Isabel." The 1880 General Land Office map shows the Port of Brownsville area within the Potrero de la Santa Isabel. The 1884 J.J. Cocke map places the Port of Brownsville area within the Rafael Garcia land grant, known as Santa Isabel (Foster et al. 2006).

According to the Port of Brownsville Historical Marker text (THC 2018), dredging of the BSC began in 1934 and the port was officially opened in 1936. A review of the Laguna Vista 1929 and 1936, Port Isabel 1929 and 1934, and Brownsville 1953 and 1962 U.S. Geological Survey topographic maps indicates that prior to the dredging of the BSC and the construction of SH 48 (initially constructed in 1952 [Weinstein et al. 2005]), portions of the eastern Port property (southwest of Loma del Rincon Chiquito) was mapped as water within the mouth of the Laguna Madre. As such, all portions of the Port property along SH 48, southwest of Loma del Rincon Chiquito that are currently elevated above the tidal flats are artificial landforms, as a result of modern construction activity, with the exception of the small loma islands that are bisected by SH 48. Tidal flats and artificial landforms composed of dredge have a low to negligible potential for intact cultural resources.

\section{FIELD SURVEY}

\section{Methods}

SWCA's field investigations consisted of an intensive pedestrian survey with systematically conducted subsurface investigations (e.g., shovel test excavations) that meet the Secretary of Interior, THC and CTA survey standards, with any deviations clearly documented. The utilization of methods was keyed to the level of disturbance and the nature of the geology, soils, and topography along the survey route. For example, areas (i.e. Port property) that were obviously fill and dredge material were not subject to subsurface investigations. Elsewhere, within areas that were significantly disturbed (i.e. collocated with existing utilities) or exhibited high surface visibility (greater than 30 percent), SWCA performed cursory surface inspection and/or more limited subsurface investigations.

Archaeologists examined the ground surface and erosional profiles and exposures for cultural resources. Subsurface investigations involved shovel testing in settings with the potential to contain buried cultural materials. Shovel tests were approximately 30 centimeters $(\mathrm{cm})$ in diameter and excavated in arbitrary 20$\mathrm{cm}$ levels to $100 \mathrm{~cm}$ below surface (cmbs) unless soil characteristics or argillic horizons precluded 
reaching that depth. The matrix from each shovel test was screened through $1 / 4$-inch mesh, and the location of each excavation was plotted using a hand-held Global Positioning System receiver. Each shovel test was recorded on a standardized digital form in SWCA's field tablets to document the excavations. No artifacts were recovered; documentation will be curated at the Texas Archeological Research Laboratory of The University of Texas at Austin.

\section{Site Evaluations}

Any discovered cultural resources would be evaluated according to the National Register Criteria for Evaluation as codified in 36 Code of Federal Regulations Chapter 60.4, which states:

The quality of significance in American history, architecture, archeology, engineering, and culture is present in districts, sites, buildings, structures, and objects that possess integrity of location, design, setting, materials, workmanship, feeling, and association and

(a) that are associated with events that have made a significant contribution to the broad patterns of our history; or

(b) that are associated with the lives of persons significant in our past; or

(c) that embody the distinctive characteristics of a type, period, or method of construction, or that represent the work of a master, or that possess high artistic values, or that represent a significant and distinguishable entity whose components may lack individual distinction; or

(d) that have yielded, or may be likely to yield, information important in prehistory or history.

Additional evaluations would be made under the Texas Administrative Code Title 13 Rule 26.10 to determine State Archaeological Landmark designation eligibility. The ACT criteria states:

The commission shall use one or more of the following criteria when assessing the appropriateness of official landmark designation, and/or the need for further investigations under the permit process:

(1) the site has the potential to contribute to a better understanding of the prehistory and/or history of Texas by the addition of new and important information;

(2) the site's archeological deposits and the artifacts within the site are preserved and intact, thereby supporting the research potential or preservation interests of the site;

(3) the site possesses unique or rare attributes concerning Texas prehistory and/or history;

(4) the study of the site offers the opportunity to test theories and methods of preservation, thereby contributing to new scientific knowledge; and

(5) there is a high likelihood that vandalism and relic collecting has occurred or could occur, and official landmark designation is needed to ensure maximum legal protection, or alternatively, further investigations are needed to mitigate the effects of vandalism and relic collecting when the site cannot be protected. 


\section{Results}

SWCA archaeologists conducted cultural resources intensive pedestrian survey of one Rio Bravo pipeline reroute and four small access roads on October 22, 2018. All are located on Port of Brownsville parcel ND-CAM-082.000, and the investigations were conducted under ACT Permit No. 8588 (Figure 6). The area has been extensively modified by the Port along with numerous existing utilities and other infrastructure. No cultural resources were encountered during the field survey efforts.

The field investigations encountered distinct microenvironments within the Project area, which are specific to the various landforms present and include areas impacted by historic and modern development. The most common setting is that of the low-lying tidal flats. These basin areas exhibit little to no topographic relief and have relatively dense, leafy wetland vegetation with scattered mesquite trees and cacti. Ground surface visibility across the flats was typically around 30 to 85 percent. Some of the lowlying flats were inundated at the time of survey, especially those along the south side of SH 48. Typical soils encountered within the tidal flats consist of brown to dark grayish brown clay with soft calcium carbonate nodules. Shovel tests in tidal areas were typically terminated at the water table or as a result of thick, sticky and saturated clay.

The next most common setting consists of fill and spoil areas. Port construction, channel dredging and maintenance has resulted in an accumulation of mottled, clayey spoils. Vegetation is absent along the majority of these areas and there can be the presence of historic to modern glass, ceramic, metal, and plastic as well as oyster and clam shells scattered across the surface of the spoils. As this mix of natural and cultural material is a result of dredging and accumulated storm debris, when encountered it was not documented as an archaeological site. Shovel tests were not excavated within the mapped areas of dredge spoils.

Another microenvironment within the Project area consists of the of low, sandy hills loma formations situated along the tidal flats. As with the fill and dredge spoils, little to no vegetation is present on the eroded sloping edges of the lomas, affording nearly 100 percent ground surface visibility where wind and water erosion has exposed stratified layers of soil. The erosional exposures were examined, and no cultural material or potential cultural features were observed. Vegetation across these less dense portions of the lomas consists of sawgrass, mesquite, and cacti. The loma ridges on the other hand, are largely covered in an extremely dense thicket of thorny south Texas vegetation consisting of mesquite, agarita, acacia, catclaw, lantana, prickly pear cacti, and Spanish dagger. Despite dense vegetation, investigators were able to survey and shovel test atop the lomas, where the potential for buried cultural deposits is generally considered greater than the surrounding areas, utilizing often abundant exposures on the margins of the landforms. As such, ground surface visibility on the lomas averaged around 20 to 30 percent at the time of survey. Soil encountered on the lomas is typically brown sandy clay loam over light grayish brown, compact clay loam with calcium carbonate concretions and filaments.

\section{Pipeline Corridor Survey}

SWCA archaeologists conducted cultural resources intensive pedestrian survey of one Rio Bravo LNG pipeline reroute on October 22, 2018 (see Figure 6). The reroute is located on Port of Brownsville parcel ND-CAM-082.000 in Cameron County, Texas. The investigations covered 0.58 mile $(0.93 \mathrm{~km})$ of proposed pipeline corridor within a 200 -foot-wide (60.96-m-wide) pipeline survey corridor. The new pipeline survey corridor parallels previously surveyed pipeline right-of-way.

The pipeline reroute consists of a narrow 0.58-mile-long shift in the line between MP 134.1 to 134.7 along the Project alignment (Figure 7). SWCA archaeologists excavated a total of nine shovel tests (CS10-13 and JU511-515) within the pipeline survey corridor all negative for cultural materials (Table 4). 
Shovel tests exhibited gray (10YR 5/1) and grayish brown (10YR 5/2) silty clay loam to clay with barely any inclusions. Shovel tests extended to a maximum depth of $60 \mathrm{~cm}$ below the surface $(\mathrm{cmbs})$ and terminated upon encountering compact soils with water table encountered in a couple of the tests. The area has been extensively modified by numerous existing utilities and other infrastructure. No cultural resources were identified within the Project Area during the pipeline corridor survey.

\section{Access Roads Survey}

SWCA archaeologists conducted cultural resources intensive pedestrian survey of four small access roads associated with the Rio Bravo LNG Pipeline Project on October 22, 2018 (see Figure 6). All are located on Port of Brownsville parcel ND-CAM-082.000 in Cameron County, Texas. The investigations covered 0.31 mile $(0.50 \mathrm{~km})$ of proposed access roads within a 50 -foot-wide $(11.24$ - m-wide) access roads survey corridor.

The access roads are all existing roads consisting of dirt roads with some gravel improvements located at Mile Posts (MPs) 131.3, 132.4, 132.8, and 134.1 along the Project alignment which have been used for previous pipeline construction (Figure 8). These access roads are improved or previously disturbed roads, which precluded the need to excavate additional shovel tests, as no grading or ditching is anticipated along these roads. The area has been extensively modified by numerous existing utilities and other infrastructure. No cultural resources were identified within the Project Area during the access roads survey. 
Cultural Resources Survey of Portions of the Rio Bravo LNG Pipeline on Port of Brownsville Lands Antiquities Code of Texas Permit 8588

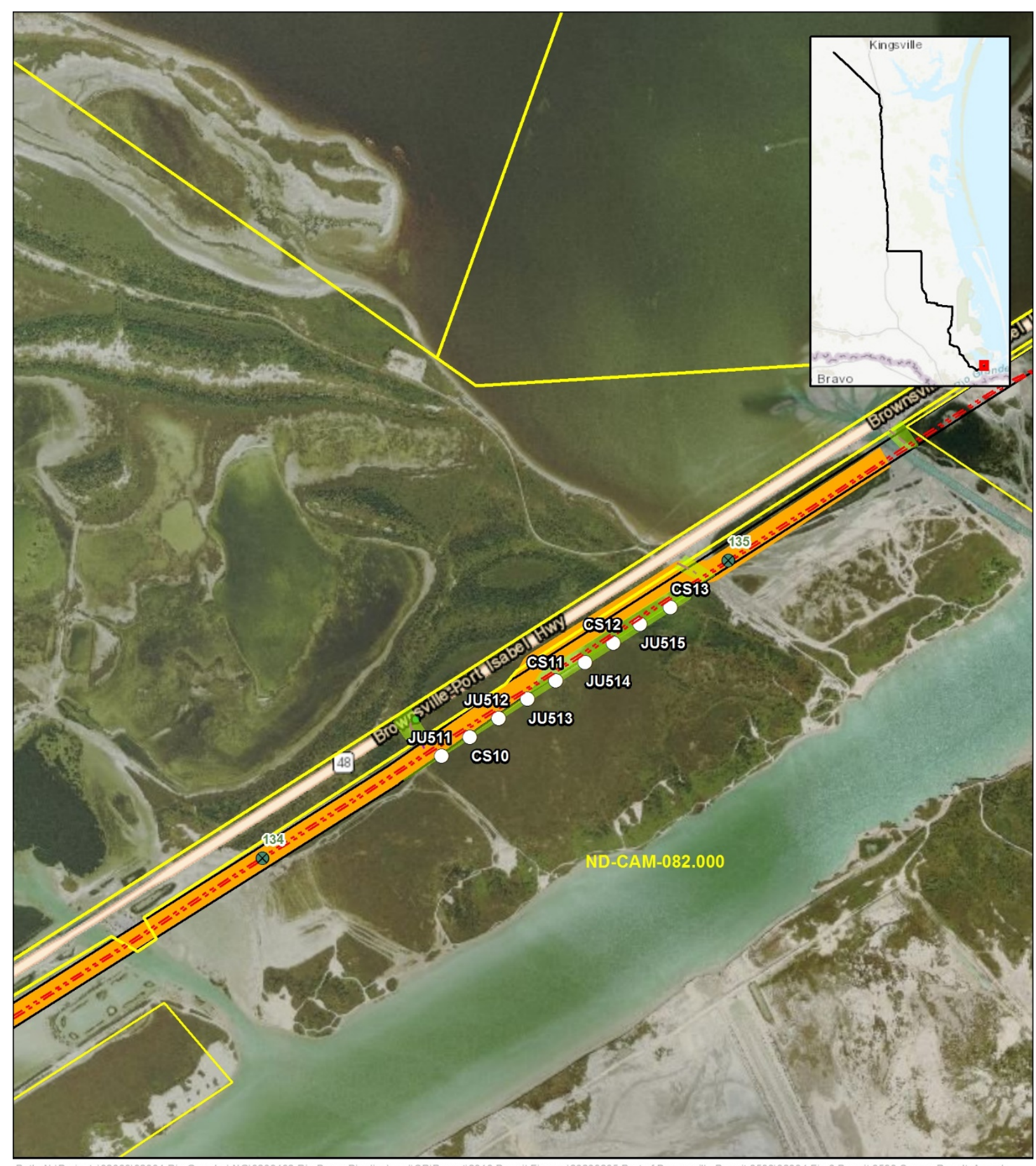

\begin{tabular}{|c|c|c|c|}
\hline & $\begin{array}{c}\text { RIO BRAVO PIPELINE } \\
\text { RESULTS MAP }\end{array}$ & $\begin{array}{cl}--- & \text { Centerline (2019) } \\
--- \text { Access Road } \\
\otimes \text { Milepost } \\
\quad \text { Survey Area } \\
\end{array}$ & 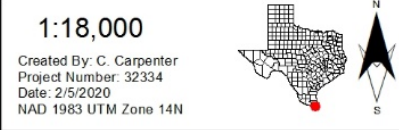 \\
\hline ENVIRONMENTAL CONSULTANTS & TEXAS & $\begin{array}{l}\text { Previous Survey Progress } \\
\text { Negative Shovel Test } \\
\text { Parcels }\end{array}$ & $\begin{array}{l}1,000 \\
\end{array}$ \\
\hline
\end{tabular}

Figure 6. Field survey results map. 
Cultural Resources Survey of Portions of the Rio Bravo LNG Pipeline on Port of Brownsville Lands Antiquities Code of Texas Permit 8588

\section{Table 4. Shovel Test Data}

\begin{tabular}{cccccccccc}
\hline $\begin{array}{c}\text { Shovel } \\
\text { Test } \\
\text { No. }\end{array}$ & Level & Depth & $\begin{array}{c}\text { Munsell } \\
\text { Value }\end{array}$ & Munsell Color & $\begin{array}{c}\text { Soil } \\
\text { Texture }\end{array}$ & $\begin{array}{c}\text { Inclusion } \\
\text { Percent }\end{array}$ & $\begin{array}{c}\text { Inclusion } \\
\text { Types }\end{array}$ & $\begin{array}{c}\text { Positive/Negative } \\
\text { for Cultural } \\
\text { Material }\end{array}$ & $\begin{array}{c}\text { Comments/ } \\
\text { Reason for Termination }\end{array}$ \\
\hline CS10 & 1 & $0-50$ & $\begin{array}{c}10 Y R \\
5 / 2\end{array}$ & Grayish Brown & Clay & $0 \%$ & None & Terminated at compact \\
soil.
\end{tabular}




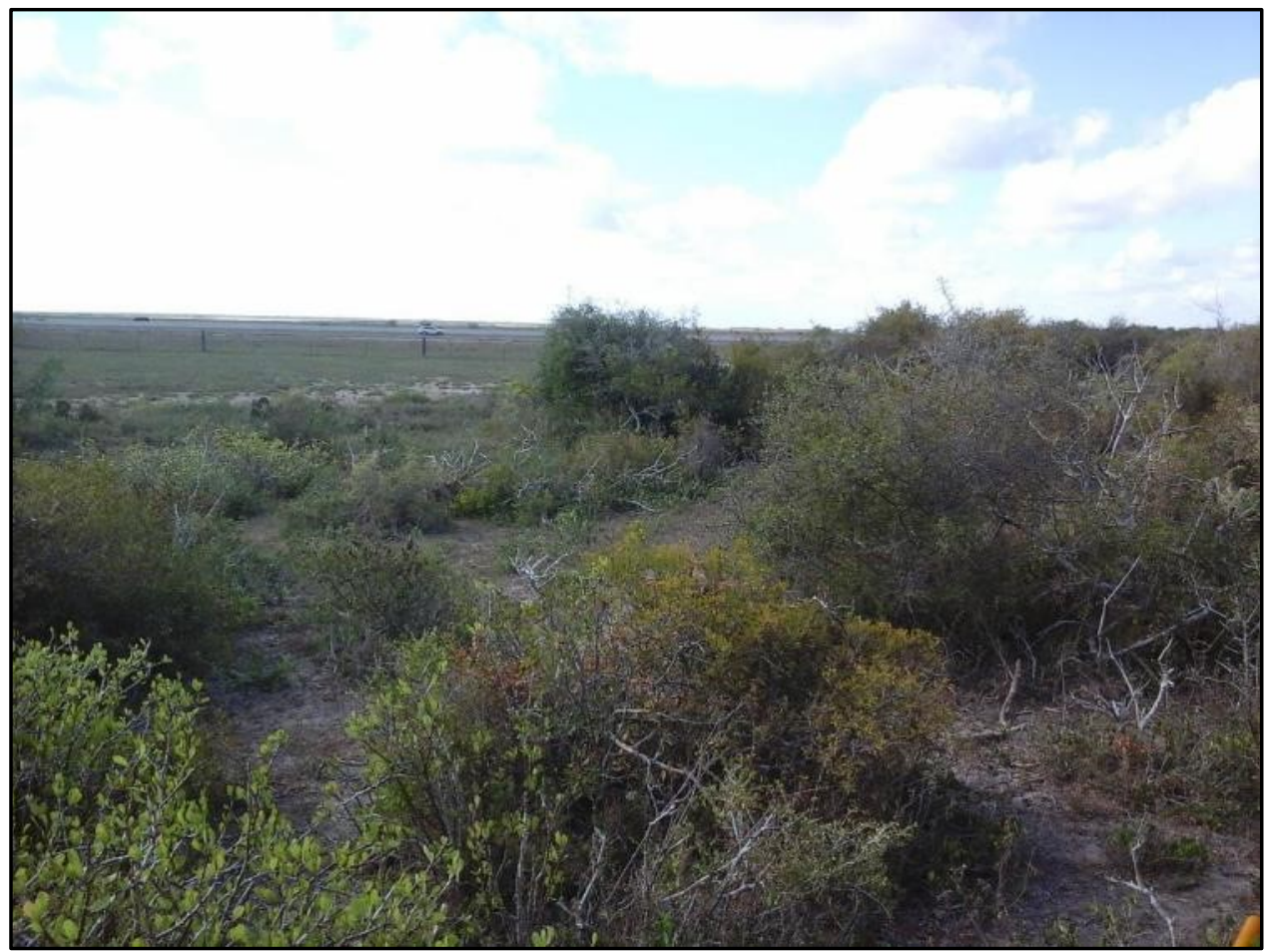

Figure 7. Overview of loma on ND-CAM-082.000, facing southeast.

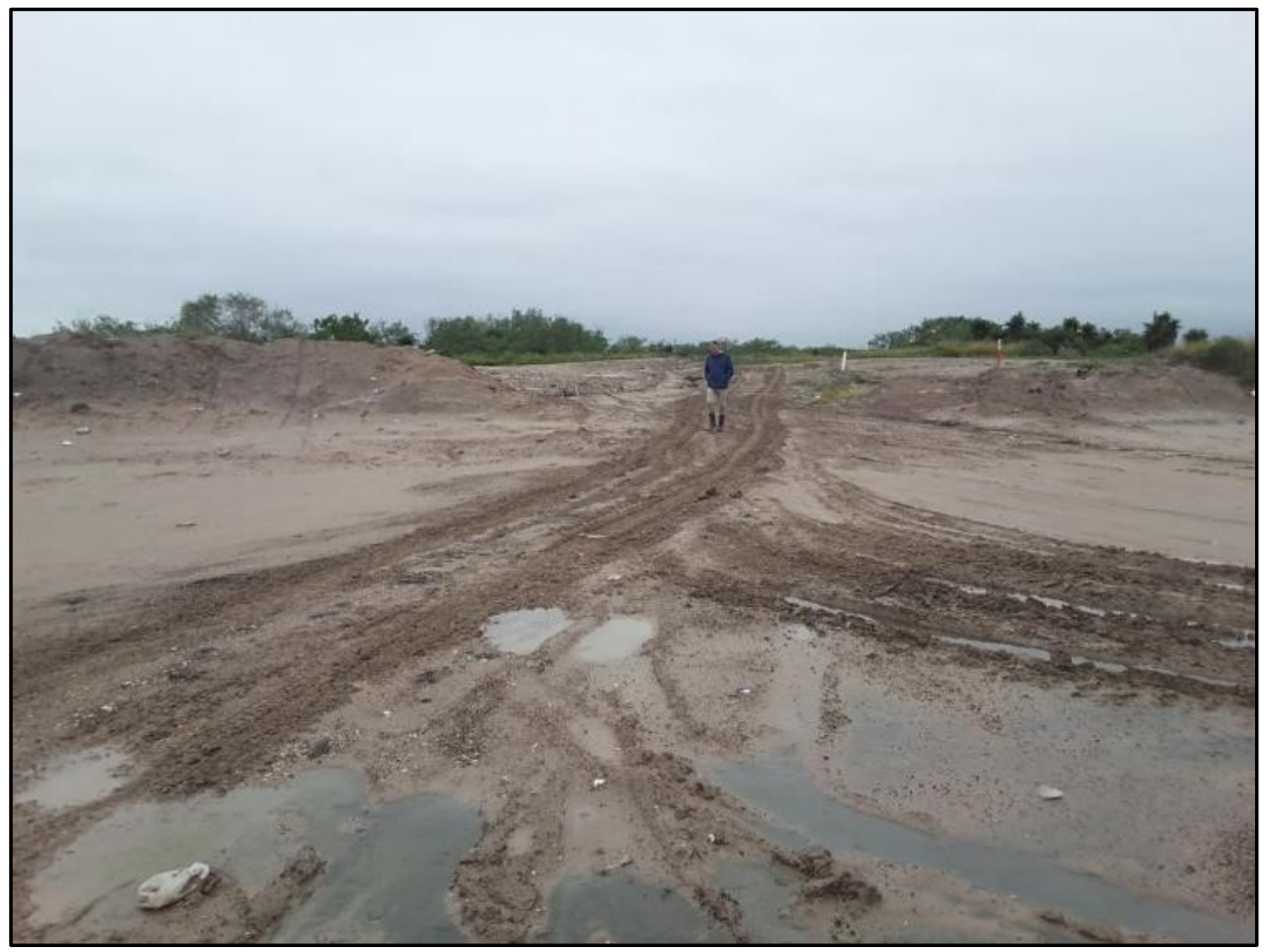

Figure 8. Existing access road on tract ND-CAM-082.000, facing south. Access road has long been in use for existing collocated pipeline marked by orange and white posts in background. Note wide road cut through low lomas near surveyor. 


\section{SUMMARY AND RECOMMENDATIONS}

On behalf of E \& E, Rio Grande LNG, LLC, and RB Pipeline, SWCA conducted cultural resources surveys of portions of the Rio Bravo Pipeline on lands owned or controlled by the Port of Brownsville in Cameron County, Texas. Rio Grande LNG, LLC proposes to construct a natural gas liquefaction facility and LNG Terminal in Cameron County, Texas, along the north embankment of the Brownsville Ship Channel. In concert with the Terminal, RB Pipeline proposes to construct an associated Pipeline System/Project within Cameron, Willacy, Kenedy, Kleberg, and Jim Wells Counties, Texas to allow for interconnection with a network of existing pipelines that traverse the northern end of Kleberg County and Jim Wells County. The proposed Pipeline System/Project will collect and transport natural gas to the Terminal site.

In compliance with the FERC and USACE permitting requirements and oversight, SWCA conducted cultural resources investigations in compliance with Section 106 of the NHPA (54 U.S.C. 306108) and its implementing regulations in 36 CFR 800 . This stand-alone report specifically addresses portions of the alignment that will be located on lands owned by the Port. Since the Port is a political subdivision of the state, investigations were conducted in compliance with the ACT under ACT Permit No. 8588. This report will serve as an addendum to the final report. The data in this report is also presented in Addendum IV (Carpenter et al., 2020) to the final report (Nielsen et al., 2016) of the overall investigations.

SWCA's cultural resources investigations included a background and historical map review, and an intensive pedestrian survey with subsurface testing. The investigations assessed approximately 0.58 mile (0.93 kilometers $[\mathrm{km}]$ ) of proposed pipeline corridor within a 200 -foot-wide (60.96-meter [m]-wide) pipeline survey corridor, and 0.31 mile $(0.50 \mathrm{~km})$ of proposed access roads within a 50 -foot-wide (15.24$\mathrm{m}$-wide) access roads survey corridor, for a Project Area total of approximately 15.8 acres within Port property.

The background literature review identified nine previously conducted cultural resources surveys within a 1-mile radius of the Project Area, three of which intersect the current Project Area. The review identified no previously recorded archaeological sites within the Project Area; however, seven archaeological sites are within a 1-mile radius none of which are immediately adjacent (within 300 feet [91.44 m]) to the Project Area. In addition, a review of historical maps determined that there are no historic-age structures or features within or immediately adjacent to the Project Area.

The field survey was conducted on October 22, 2018 and revealed an extensively disturbed setting due to historic \& modern development in the area mainly associated with the Port. SWCA archaeologists excavated a total of nine shovel tests within the Project Area all negative for cultural materials. No cultural materials or features or historic-age structures were identified within the Project Area during the field survey.

In accordance with the ACT and Section 106 of the NHPA, SWCA has made a reasonable and good faith effort to identify cultural resources within the area of potential effects. No cultural resources were identified within the Project Area during the current investigations. Accordingly, no further investigation is recommended for the assessed sections of the Project Area. The THC concurred with these findings and recommendations on January 14, 2020. No artifacts were recovered; documentation will be curated at the Texas Archeological Research Laboratory of The University of Texas at Austin. 


\section{REFERENCES}

Barnes, V. E.

1976 Geologic Atlas of Texas, McAllen-Brownsville Sheet. Bureau of Economic Geology, The University of Texas at Austin.

Carpenter, Steve, Christopher Shelton, Ben Morton, and Victoria Myers

2020 Final Addendum IV Report: Cultural Resources Survey of Additional Areas of the Rio Bravo Pipeline Project, Cameron, Willacy, and Kenedy Counties, Texas. SWCA Cultural Resources Report No. 16-491, Austin, Texas.

Fisher, W. L.

1976 Geologic Atlas of Texas, McAllen-Brownsville Sheet. Bureau of Economic Geology, The University of Texas at Austin.

Foster, T. R., T. Summerville, and T. Brown

2006 The Texas Historic Overlay: A Geographic Information System of Historic Map Images for Planning Transportation Projects in Texas. Prepared for the Texas Department of Transportation by PBS\&J, Austin.

Nielsen, Christina, Steve Carpenter, and Mercedes C. Cody

2016 Cultural Resources Survey of the NextDecade, LLC, Rio Bravo Liquefied Natural Gas Pipeline and Unsurveyed Lands Associated with the Rio Grande LNG Export Terminal, Cameron, Willacy, Kenedy, Kleberg, and Jim Wells Counties, Texas. SWCA Cultural Resources Report No. 15-557, Austin, Texas.

National Resources Conservation Services (NRCS)

2015 Web Soil Survey. United States Department of Agriculture, Washington, D.C. Available at http://websoilsurvey.nrcs.usda.gov/app/WebSoilSurvey.aspx. Accessed on October 2015.

Stotts, Matthew C., and Steve Carpenter

2015 Cultural Resources Survey of the NextDecade, LLC, Rio Grande Liquefied Natural Gas Export Terminal, Port of Brownsville, Cameron County, Texas. SWCA Cultural Resources Report No. 15-215, Austin, Texas.

Texas Historical Commission (THC)

2018 Texas Archaeological Site Atlas restricted database, Texas Historical Commission. Available at: http://nueces.thc.state.tx.us/. Accessed on September, 2018.

2019 Texas Archaeological Site Atlas restricted database, Texas Historical Commission. Available at: http://nueces.thc.state.tx.us/. Accessed on October 6, 2019.

U.S. Geological Survey (USGS)

2019 The National Geologic Map Database (TopoView). Historical topographic map collection. Available at: http://ngmdb.usgs.gov/maps/TopoView/. Accessed October 2015.

Weinstein, Richard A., Pollyanna A. Held, and Robert A. Ricklis

2005 Cultural Resources Survey and Preliminary Site Assessment within Six Right-of-Way Areas, State Highway (SH) 48, Port Isabel to Brownsville, Cameron County, Texas. TxDOT Environmental Affairs Division. Archaeological Studies Branch, Report No. 70. Coastal Environments, Inc. Baton Rouge, Louisiana. 